\title{
The prognostic value of white blood cell count-to-mean platelet volume ratio in patients with acute coronary syndrome
}

We have read the article entitled "White blood cell count to mean platelet volume ratio as a novel non-invasive marker predicting long-term outcomes in patients with non-ST elevation acute coronary syndrome" [1] with great interest. Both leukocytes and platelets have been reported to be involved in several cardiovascular (CV) diseases through inflammatory pathways. The close relationship between inflammation, aggregation, and atherosclerosis progression has become a field of intensive research. The study by Dehghani et al. [1] evaluated the predictive role of white blood cell count/mean platelet volume (WBC/MPV) ratio (WMR) in long-term outcomes of acute coronary syndrome (ACS) patients. However, we have some comments regarding the presented study.

Previous studies revealed an association between higher rates of major adverse cardiac events and poorer outcomes with both higher platelet and lower lymphocyte counts [2-4]. The advantage of the platelet-to-lymphocyte ratio (PLR) is that it reflects both hyperactive aggregation and inflammatory pathways, and it may be superior to either the individual platelet or the lymphocyte counts in the prediction of long-term outcome in CV diseases. Azab et al. [5] showed that higher PLR values are associated with higher long-term mortality in patients presenting with non-ST segment elevation ACS. Several additional studies have appeared recently, that integrate the predictive risk of this novel marker, PLR, in ACS settings [6-9]. As increased platelet count and decreased lymphocyte levels are associated with poor CV outcome, it is logical to integrate these 2 parameters into 1. White blood cell count and its differential, C-reactive protein and the neutrophil-to-lymphocyte ratio are some of the inflammatory markers that were demonstrated to have predictive and prognostic significance in a wide range of $\mathrm{CV}$ diseases including ACS [10-12]. On the other hand, MPV is another recent hematologic parameter being extensively investigated. A number of studies have demonstrated that higher MPV values are associ- ated with poorer long-term outcome in patients presented with ACS [13-15]. Therefore, increased levels of both WBC and MPV levels were shown to be associated with adverse $\mathrm{CV}$ outcomes; the proposed novel marker, WMR, would most likely blunt the predictive power of these parameters, as a result of dividing WBC by MPV.

\section{Conflict of interest: None declared}

\section{References}

1. Dehghani MR, Rezaei Y, Taghipour-Sani L. White blood cell count to mean platelet volume ratio as a novel non-invasive marker predicting long-term outcomes in patients with non-ST elevation acute coronary syndrome. Cardiol J, 2015; doi: 10.5603/ /CJ.a2015.0015 [Epub ahead of print].

2. Nikolsky E, Grines CL, Cox DA et al. Impact of baseline platelet count in patients undergoing primary percutaneous coronary intervention in acute myocardial infarction (from the CADILLAC trial). Am J Cardiol, 2007; 99: 1055-1061.

3. Ommen SR, Hodge DO, Rodeheffer RJ, McGregor CG, Thomson SP, Gibbons RJ. Predictive power of the relative lymphocyte concentration in patients with advanced heart failure. Circulation, 1998; 97: 19-22.

4. Zouridakis EG, Garcia-Moll X, KaskiJC. Usefulness of the blood lymphocyte count in predicting recurrent instability and death in patients with unstable angina pectoris. Am J Cardiol, 2000; 86: 449-451.

5. Azab B, Shah N, Akerman M, McGinn JT, Jr. Value of platelet/ /ymphocyte ratio as a predictor of all-cause mortality after nonST-elevation myocardial infarction. J Thrombosis Thrombolysis, 2012; 34: 326-334.

6. Yildiz A, Yuksel M, Oylumlu M et al. The utility of the platelet-lymphocyte ratio for predicting no reflow in patients with ST-segment elevation myocardial infarction. Clinical Applied Thrombosis/Hemostasis, 2015; 21: 223-228.

7. Acet H, Ertas F, Akil MA et al. Novel predictors of infarctrelated artery patency for ST-segment elevation myocardial infarction: Platelet-to-lymphocyte ratio, uric acid, and neutrophilto-lymphocyte ratio. Anatolian J Cardiol, 2014; doi: 10.5152/ /akd.2014.5592 [Epub ahead of print].

8. Oylumlu M, Yildiz A, Oylumlu M et al. Platelet-to-lymphocyte ratio is a predictor of in-hospital mortality patients with acute coronary syndrome. Anatolian J Cardiol, 2015; 15: 277-283.

9. Acet H, Ertas F, Akil MA et al. Relationship between hematologic indices and global registry of acute coronary events risk score in patients with ST-segment elevation myocardial infarction. Clin App Thromb Hemost, 2014; May 8 [Epub ahead of print]. 
10. Celik T, Iyisoy A, Yuksel UC, Jata B, Ozkan M. The impact of admission C-reactive protein levels on the development of noreflow phenomenon after primary PCI in patients with acute myocardial infarction: The role of inflammation. Int J Cardiol, 2009; 136: 86-88; author reply: 88-89.

11. Sen N, Afsar B, Ozcan F et al. The neutrophil to lymphocyte ratio was associated with impaired myocardial perfusion and long term adverse outcome in patients with ST-elevated myocardial infarction undergoing primary coronary intervention. Atherosclerosis, 2013; 228: 203-210.

12. Hartaigh B, Bosch JA, Thomas GN et al. Which leukocyte subsets predict cardiovascular mortality? From the LUdwigshafen
RIsk and Cardiovascular Health (LURIC) Study. Atherosclerosis, 2012; 224: 161-169.

13. Wan ZF, Zhou D, Xue JH et al. Combination of mean platelet volume and the GRACE risk score better predicts future cardiovascular events in patients with acute coronary syndrome. Platelets, 2014; 25: 447-451.

14. Niu X, Yang C, Zhang Y, Zhang H, Yao Y. Mean platelet volume on admission improves risk prediction in patients with acute coronary syndromes. Angiology, 2015; 66: 456-463.

15. Ozlu MF, Ozturk S, Ayhan SS et al. Predictive value of mean platelet volume in young patients with non-ST-segment elevation acute coronary syndromes: A retrospective observational study. Anatolian J Cardiol, 2013; 13: 57-61.

Murat Yuksel, Abdulkadir Yildiz, Murat Cayli Department of Cardiology, Dicle University School of Medicine Kalp Hastanesi Kardiyoloji AD, 21280, Sur, Diyarbakir, Turkey tel: (+90) 412 2488001, fax: (+90) 4122488523 e-mail:yukselmurat@yahoo.com 